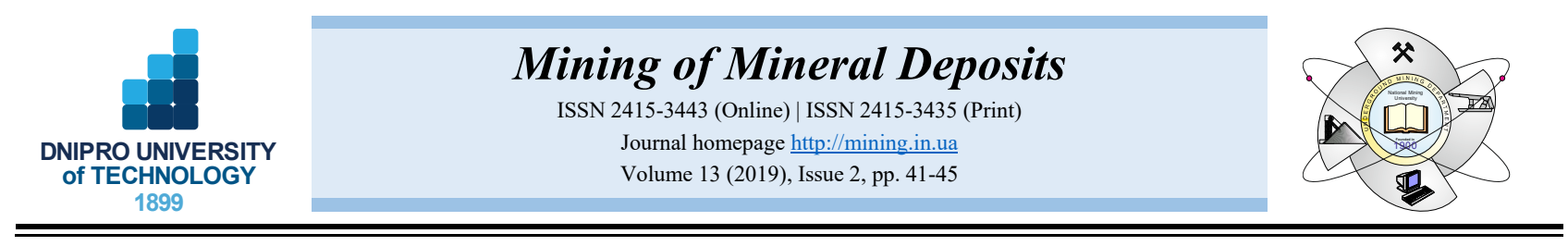

UDC 622.276 .4

https://doi.org/10.33271/mining13.02.041

\title{
STUDY OF NUMERICAL SIMULATION METHOD MODELLING GAS INJECTION INTO FRACTURED RESERVOIRS
}

\author{
Z. Yun ${ }^{1 *}$, S. Jianfang ${ }^{1}$, L. Zhongchun ${ }^{1}$ \\ ${ }^{I}$ Sinopec Petroleum Exploration and Production Research Institute, Beijing, China \\ *Corresponding author: e-mail zhangyun.syky@sinopec.com, tel. +861082311035
}

\begin{abstract}
Purpose. Fractures are the main flow channels in fractured reservoirs. The rapid flow characteristics of gas are outstanding in fractures. It is a major technical problem in the current oilfield development to calculate and accurately describe the fluid flow of this type of reservoir.

Methods. This paper improves the calculation model of oil-water-gas phase equilibrium. Based on the discrete fracture net-work model, the numerical simulation mathematical model, numerical model and solution method of nitrogen injection were established.

Findings. A simple discrete fracture network model was designed. Numerical simulations verify the correctness of the method.

Originality. A fast solution method for gas injection numerical simulation based on discrete crack network model is proposed.

Practical implications. The fractured reservoir numerical simulation method can accurately describe the flow of oil, water and gas in the fracture, which lays a foundation for the gas injection development mechanism and gas injection optimization research.
\end{abstract}

Keywords: fractured reservoir, numerical simulation, discrete fracture network model, gas injection

\section{INTRODUCTION}

The world's fractured reservoir resources account for more than half of the total resources. It is also widely distributed in China (Li, 2013). However, due to the large difference between the fluid flow and the matrix in the fracture, the numerical simulation of the reservoir is inadequate (Yang et al., 2017). As of today, there are no efficient simulation method. After gas injection, the simulation is more difficult. Traditional gas injection numerical simulation methods are no longer applicable. Therefore, the development of gas injection in this type of reservoir lacks theoretical basis and technical support. Therefore, it is necessary to study the numerical simulation method of gas injection in this type of reservoir (Li \& Jia, 1994).

The scale of the fracture medium in the fractured reservoir varies greatly. There are large-scale fractures, mesoscale fractures, small-scale fractures, and microfractures. The fluid flow capacity varies greatly in different media. Mathematical descriptions and numerical solutions are difficult (Yuan \& Song, 2004). The high fluidity of the gas phase makes the numerical simula- tion of the gas injection more astringent and slow. For the numerical simulation of this type of reservoir, the current numerical simulation model is mainly a dual medium model and a discrete fracture network model. The dual medium model was proposed as early as the 1960s (Warren \& Root, 1963). The model is now mature and is guiding the development of this type of reservoir. However, it has a large error in the fluid flow in large fractures, thus it is impossible to describe the fluid flow in large fractures. The discrete fracture network model was proposed in 2001 by M. Karimi-Fard and A. Firoozabadi (Kazemi, Merrill, Porterfield, \& Zeman, 1976; Karimi-Fard \& Firoozabadi, 2001; Berkowitz, 2002; Karimi-Fard \& Firoozabadi, 2003). It has good pseudo-performance and can describe the flow of fluid in large fractures. The Discrete Fracture Network (DFN) model has been highly recognized by experts and scholars at home and abroad (Zhang, Jia, Zhang, \& Guo, 2017). Therefore, gas injection numerical simulation method in fractured reservoirs is proposed based on discrete fracture network model.

(C) 2019. Z. Yun, S. Jianfang, L. Zhongchun. Published by the Dnipro University of Technology on behalf of Mining of Mineral Deposits. 


\section{PHASE BALANCE CALCULATION METHOD}

Gas injection development in the reservoir will affect the phase balance of the reservoir. Phase equilibrium calculation is the basis for numerical simulation of gas injection. The traditional phase equilibrium calculation methods mainly include the equilibrium constant method and the flash calculation method based on the Rachford-Rice equation (Wen \& Guanren, 1992; Jigen \& Yufeng, 1996). The equilibrium constant method does not take into account the effects of different compositions of crude oil. The flash calculation method is mainly used for phase equilibrium calculation of gasliquid two-phase system (Yingsheng, Fang, \& Xingang, 1990; Pedersen, 1995).

A phase equilibrium calculation method based on Gibbs free energy is proposed for this purpose. The specific method comprises the Gibbs free energy expression, the phase fractional constraint equation and the mass conservation equation of the multiphase multicomponent system (Haiyan \& Shilun, 2000). Then the objective function is determined. The Newton iterative method is used to solve the composition of each phase in the Gibbs free energy minimum.

\section{Calculation equation.}

When the Gibbs free energy is minimal, the system reaches phase equilibrium:

$$
G=\sum_{k=1}^{\pi} \sum_{i=1}^{C} n_{i k} \mu_{i r}+\sum_{\substack{k=1 \\ k \neq r}}^{\pi} \sum_{i=1}^{C} n_{i k}\left(\mu_{i k}-\mu_{i r}\right) .
$$

\section{Constraint equation.}

The phase scores of each phase are:

$$
\alpha_{k}=\sum_{i=1}^{C} \frac{n_{i k}}{n_{t}}, k=1, \ldots, \pi ; k \neq r ;
$$

$\alpha_{r}=1-\sum_{\substack{k=1 \\ k \neq r}}^{\pi} \alpha_{k} ;$

$$
n_{t}=\sum_{i=1}^{C} \sum_{k=1}^{\pi} n_{i k}
$$

The mass fraction of each component is calculated using the law of mass conservation:

$$
\begin{gathered}
x_{i r}=\frac{z_{i}}{1+\sum_{\substack{k=1 \\
k \neq r}}^{\pi} \alpha_{k}\left(K_{i, k r} e^{\theta_{k}}-1\right)}, i=1, \ldots, C ; \\
x_{i k}=\frac{z_{i} K_{i, k r} e^{\theta_{k}}}{1+\sum_{\substack{j=1 \\
j \neq r}}^{\pi} \alpha_{j}\left(K_{i, j r} e^{\theta_{j}}-1\right)}, i=1, \ldots, C .
\end{gathered}
$$

\section{Solution method.}

Using the Lagrange function $G^{*}$, this calculation is transformed into a problem of solving $G^{*}$ minimization:

$$
G^{*}=G+\sum_{\substack{k=1 \\ k \equiv r}}^{\pi} \lambda_{k}\left(\alpha_{k}-\sum_{i=1}^{C} \frac{n_{i k}}{n_{t}}\right) \text {. }
$$

Normalization of the equation:

$$
\begin{gathered}
{\left[\begin{array}{lll}
\frac{\partial E_{k}}{\partial \alpha_{k}} & \frac{\partial E_{k}}{\partial \theta_{k}} & \frac{\partial E_{k}}{\partial x_{i k}} \\
\frac{\partial F_{k}}{\partial \alpha_{k}} & \frac{\partial F_{k}}{\partial \theta_{k}} & \frac{\partial F_{k}}{\partial x_{i k}} \\
\frac{\partial D_{i k}}{\partial \alpha_{k}} & \frac{\partial D_{i k}}{\partial \theta_{k}} & \frac{\partial D_{i k}}{\partial x_{i k}}
\end{array}\right]_{p}\left[\begin{array}{c}
\Delta \alpha_{k} \\
\Delta \theta_{k} \\
\Delta x_{i k}
\end{array}\right]_{p+1}=-\left[\begin{array}{c}
E_{k} \\
F_{k} \\
D_{i k}
\end{array}\right]_{p} .} \\
k=1, \ldots, \pi ; i=1, \ldots, C
\end{gathered}
$$

Finally, the phase equilibrium constant is solved by Newton iteration. Then the content of each component is calculated.

\section{DISCRETE FRACTURE NETWORK MODEL}

The variation in fracture size is large in fractured reservoirs. Small and medium-scale fractures and microfractures are equivalent to the matrix (Yao, Wang, Zhang, \& Huang, 2010; Yun, Xiang-Chun, Jun, ZhiJiang, \& Shu-Yue, 2010). Large fractures are described separately by discrete fractures. That is to say, the DFN model is adopted. The model explicitly treats the fracture. According to the distribution of fracture development described in the geological aspect, the model is given as far as practical considerations in numerical simulation (Fig. 1).

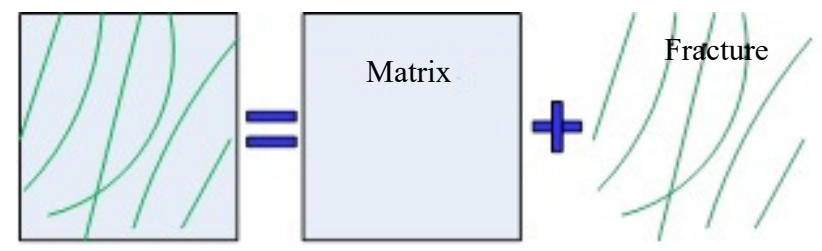

Figure 1. DFN model decomposition

$\iint_{\Omega} F E Q d \Omega=\iint_{\Omega_{m}} F E Q d \Omega_{m}+e \cdot \int_{\Omega_{f}} F E Q d \bar{\Omega}_{f}$,

where:

$F E Q$ - the flow equation of bedrock and fracture media; $\Omega$ - the entire integral area, which contains the area of the bedrock and fractures;

$\Omega_{m}$ - the matrix portion;

$\bar{\Omega}_{f}$ - the fracture in the entire integration area.

\section{GAS INJECTION NUMERICAL SIMULATION OF MATHEMATICAL MODEL AND NUMERICAL MODEL}

\subsection{Mathematical model}

Fractured reservoirs are considered to be isothermal and in thermodynamic equilibrium (Hao, Yanchun, Yingchun, \& Yue-Jie, 2014). They also contain threephase fluids comprised of oil, water and gas. The fluid of each phase flows under the impact of pressure, gravity and capillary forces.

1. Mass conservation equation.

According to the gas injection non-mixing conditions, the injected gas is considered to be juxtaposed with oil, gas and water, without mass transfer between the phases. 
The mass conservation equations of oil, water, gas and injected gas in fractures and matrix are established:

$\nabla\left(\rho_{i} v_{i}\right)+q_{i}=-\frac{\partial}{\partial t}\left(\varphi S_{i} \rho_{i}\right), i=o, w, g$

2. Multiphase flow equation of motion.

Combining the physical experiments of oil, water, gas and injected gas flow in different media, the multi-phase fluid flow equation has been established.

The equations of fluid motion in the matrix and small- and medium-scale fractures are as follows:

$v_{p i}=-\frac{K K_{r i}}{\mu_{i}}\left(\nabla p_{i}-\rho_{i} F\right), i=o, w, g$.

Equation of fluid motion in large fractures:

$\frac{\partial}{\partial t}\left(S_{i} \rho_{i} v_{i}\right)=-\nabla p_{i}+\frac{\mu_{i}}{3} \nabla\left(\nabla \cdot v_{i}\right)+$

$+\mu_{i} \nabla^{2} v_{i}, i=o, w, g$.

3. Equation of state.

Fluid compression factor:

$C_{i}=\frac{1}{\rho_{i}} \cdot \frac{d \rho_{i}}{d p_{i}}, i=o, w, g$.

Rock compression factor:

$C_{\varphi}=\frac{1}{v_{p}} \cdot \frac{d v_{p}}{d p}=\frac{1}{\phi} \cdot \frac{d \phi}{d p}$.

4. Auxiliary equation:

$S_{o}+S_{w}+S_{g}=1$.

\subsection{Numerical model and solution method}

Mass conservation equation using finite volume method for spatial dispersion, and the backward firstorder difference is used for time dispersion (Arbogast \& Brunson, 2007; Yuan, Peng, Wu, \& Kang, 2013). The equation for the mass conservation equation of oil and water discretized at element $i$ or node $i$ is as follows:

$\left[\left(M_{\beta}\right)_{i}^{n+1}-\left(M_{\beta}\right)_{i}^{n}\right] \cdot \frac{V_{i}}{\Delta t}=\sum_{j \in \eta_{i}} F_{\beta, i j}^{n+1}+Q_{\beta i}^{n+1}$,

where:

$M$ - the mass of the phase;

$n$ - the amount of the previous moment;

$n+1-$ the amount of the current moment;

$V_{i}$ - the volume of the unit $i$

$t$ - the time step;

$i-$ a set consisting of all the unit $j$ connected to the same element $i$;

$F_{\beta, i j}$ - the mass flow term between the unit $i$ and the element $j$;

$Q_{\beta i}$ - the source/sink of the phase in the unit $i$.

The rate item $k_{r} \beta$ adopts the upwind scheme.

The discrete equation is expressed as a residual form. The adaptive implicit method is used for the simulation calculation. For grids with less saturation and pressure changes, the implicit solution pressure display saturation (IMPES) algorithm is used for calculation. The oil phase pressure $P_{o}$ is selected as the main variable, and the residual of the oil component is as shown in the following formula:

$R_{i}^{o, n+1}=\left\{\left[\varphi S_{o} \bar{\rho}_{o}\right]_{i}^{n+1}-\left[\varphi S_{o} \bar{\rho}_{o}\right]_{i}^{n}\right\} \times$

$\times \frac{V_{i}}{\Delta t}-\sum_{j \in \eta_{i}}\left(\bar{\rho}_{o} \lambda_{o}\right)_{i j+\frac{1}{2}}^{n} \gamma_{i j} \times$

$\times\left[\psi_{o j}^{n+1}-\psi_{o i}^{n+1}\right]-Q_{o i}^{n+1}=0$.

The iterative formula of the Newton-Raphson method:

$\left.\frac{\partial R_{i}^{o, n+1}}{\partial P_{o}}\right|_{p}\left(P_{o, p+1}-P_{o, p}\right)=-R_{i}^{o, n+1}\left(P_{o, p}\right)$.

For the grid with less saturation and pressure change, after the oil phase pressure is solved for each time step, the corresponding oil saturation and gas saturation are calculated according to the following formula. If the saturation change within the step exceeds the limit of adaptive implicit permission, the grid is switched to implicit, otherwise it continues to be calculated according to IMPES:

$\frac{\partial R_{i}^{w, n+1}}{\partial S_{w}}\left(S_{w}^{n+1}-S_{w}^{n}\right)=-R_{i}^{w, n+1}\left(S_{w}^{n}, P_{o}^{n+1}\right) ;$

$\frac{\partial R_{i}^{g, n+1}}{\partial S_{g}}\left(S_{g}^{n+1}-S_{g}^{n}\right)=-R_{i}^{g, n+1}\left(S_{g}^{n}, P_{o}^{n+1}\right)$.

Finally, an iterative method is used to solve the problem.

\section{METHOD VERIFICATION}

A fractured reservoir model is set. The fracture opening is $1 \mathrm{~cm}$. The initial temperature is $120^{\circ} \mathrm{C}$. The fracture porosity is 0.01 , permeability $1 \mathrm{~d}$; matrix porosity 0.2 . The penetration rate is $20 \mathrm{md}$. The model is set to inject gas at the left end and oil at the right end. For ease of verification, it is equivalent to the discrete fracture network model of Figure 2. The model is a vertical sectional view.

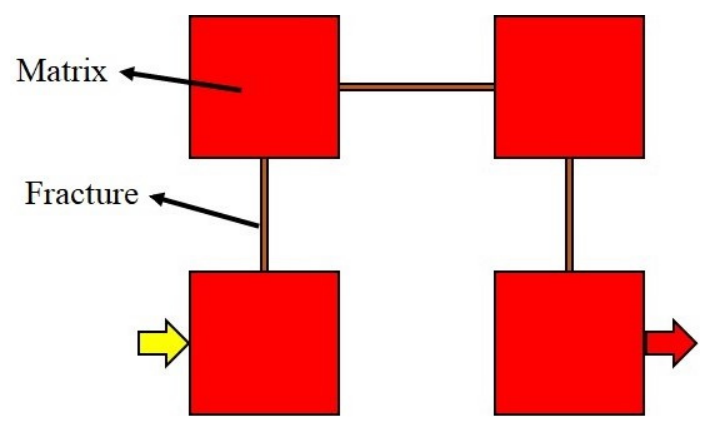

Figure 2. Discrete fracture network simulation model

The numerical simulation calculation was carried out using the set discrete fracture network model. The calculation results are shown in Figure 3. 


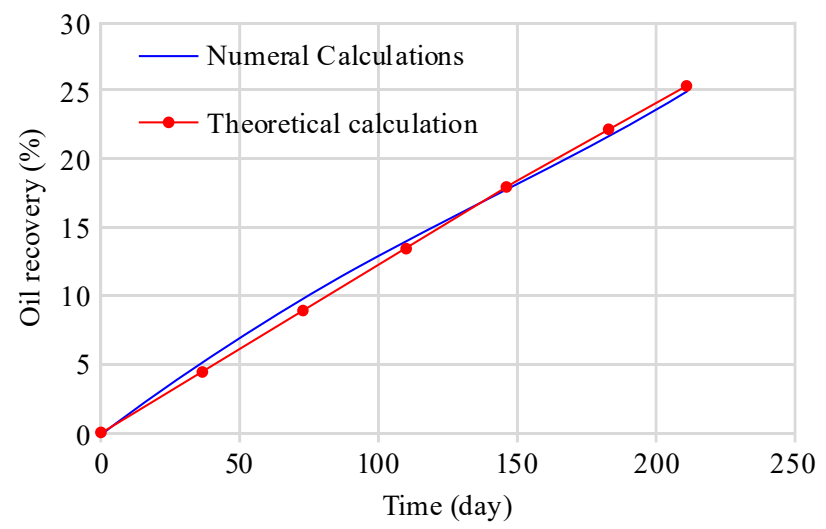

Figure 3. DFN model gas injection numerical simulation recovery curve

It can be seen from the Figure 3 that the numerical simulation results of the recovery curve are consistent with the theoretical calculation results. The correctness of the method was verified.

\section{CONCLUSIONS}

Based on the discrete fracture network model, the mathematical model, numerical model and solution method for numerical simulation of gas injection in fractured reservoirs are formed. The correctness of the method is verified by a simplified discrete fracture network model.

\section{ACKNOWLEDGEMENTS}

Project supported by National Science Foundation (No. 51674285), Major National Science and Technology Special Projects (2016ZX05014-004).

\section{REFERENCES}

Arbogast, T., \& Brunson, D.S. (2007). A computational method for approximating a Darcy-Stokes system governing a vuggy porous medium. Computational Geosciences, 11(3), 207-218. https://doi.org/10.1007/s10596-007-9043-0

Berkowitz, B. (2002). Characterizing flow and transport in fractured geological media: A review. Advances in Water Resources, 25(8-12), 861-884. https://doi.org/10.1016/s0309-1708(02)00042-8

Haiyan, M., \& Shilun, L. (2000). Phase equilibrium calculation of the gas liquid solid three phase in oil gas system. Natural Gas Industry, 1-9.

Hao, Z., Yanchun, S., Yingchun, Z., \& Yue-Jie, W. (2014). The numerical simulation study on percolation characteristics and displacement mechanism of fractured reservoir. Petroleum Geology and Recovery Efficiency, 1-13.

Jigen, Y., \& Yufeng, Q., (1996). An optimal method for flash calculations of multl compositions. Journal of Petroleum Exploration and Development, 1-12.
Karimi-Fard, M., \& Firoozabadi, A. (2001). Numerical simulation of water injection in 2D fractured media using discretefracture model. Proceedings of SPE Annual Technical Conference and Exhibition, 1-16. https://doi.org/10.2523/71615-ms

Karimi-Fard, M., \& Firoozabadi, A. (2003). Numerical simulation of water injection in fractured media using the discretefracture model and the Galerkin method. SPE Reservoir Evaluation \& Engineering, 6(02), 117-126. https://doi.org/10.2118/83633-pa

Kazemi, H., Merrill, L.S., Porterfield, K.L., \& Zeman, P.R. (1976). Numerical simulation of water-oil flow in naturally fractured reservoirs. Society of Petroleum Engineers Journal, 16(06), 317-326. https://doi.org/10.2118/5719-pa

Li, F., \& Jia, W. (1994). Mechanism of numerical simulation of immiscibie gas-drive. Petroleum Geology \& Oilfield Development in Daqing, (03),1-12.

Li, Y. (2013). The theory and method for development of carbonate fractured-cavity reservoirs in Tahe oilfield. Acta Petrolei Sinica, 34(1), 115-121. https://doi.org/10.7623/syxb201301013

Pedersen, K.S. (1995). Prediction of cloud point temperatures and amount of wax precipitation. SPE Production \& Facilities, 10(01), 46-49. https://doi.org/10.2118/27629-pa

Warren, J.E., \& Root, P.J. (1963). The behavior of naturally fractured reservoir. The Fall Meeting of the Society of Petroleum Engineers, 245-255.

Wen, S., \& Guanren, H. (1992). Flash calculation for the phase equilibrium of a $\mathrm{CO}_{2}$ - hydrocarbon - water system. Journal of Petroleum Exploration and Development, 1-9.

Yang, Y., Liu, Z., Sun, Z., An, S., Zhang, W., Liu, P., \& Ma, J. (2017). Research on stress sensitivity of fractured carbonate reservoirs based on CT technology. Energies, 10(11), 1833. https://doi.org/10.3390/en10111833

Yao, J., Wang, Z.S., Zhang, Y., \& Huang, Z. (2010). Numerical simulation method of discrete fracture network for naturally fractured reservoirs. Acta Petrolei Sinica, 31(2), 284-288.

Yingsheng, D., Fang, C., \& Xingang, L. (1990). Three-phase flash calculation and initial values problem in oil-water systems. Journal of Chemical Engineering, 1-10.

Yuan, D., Peng, L., Wu, Y.-S., \& Kang, Z.-J. (2013). Numerical simulation of multiphase flow in fractured vuggy porous medium using finite volume method. Chinese Journal of Computational Mechanics, (30), 144-149. https://doi.org/10.7511/jslx2013z031

Yuan, S., \& Song, X. (2004). Development technology of fractured reservoirs. Beijing, China: Petroleum Industry Press.

Yun, Z., Xiang-Chun, Y., Jun, Y., Zhi-Jiang, K., \& Shu-Yue, C. (2010). Discrete fracture numerical simulation methods for reservoirs. Journal of Daqing Petroleum Institute, (03), 1-9.

Zhang, L., Jia, M., Zhang, R., \& Guo, J. (2017). Discrete fracture network modeling and numerical simulation of fractured reservoirs. Journal of Southwest Petroleum Institute: Natural Science Edition. https://doi.org/10.11885/i.issn.1674-5086.2016.03.31.03

\section{ВИВЧЕННЯ МЕТОДИКИ ЧИСЕЛЬНОГО МОДЕЛЮВАННЯ ВПОРСКУВАННЯ ГАЗУ У ТРІЩИНУВАТІ КОЛЕКТОРИ}

\section{3. Юнь, С. Цзяньфан, Л. Чжуньчунь}

Мета. Розробка нової методики чисельного моделювання впорскування газу у тріщинуваті колектори на основі моделі дискретної мережі тріщин.

Методика. Для досягнення поставленої мети виконано критичний аналіз відомих методів моделювання, що довів відсутність на сьогоднішній день ефективних методів. Для дослідження проблемних питань у статті застосовано метод розрахунку фазової рівноваги на основі вільної енергії Гіббса як основи для чисельного моде- 
лювання закачування газу. Використовували ітераційний метод Ньютона для визначення складу кожної фази в мінімумі вільної енергії Гіббса.

Результати. На основі моделі дискретної мережі тріщин сформовані математична модель, чисельна модель $i$ метод рішення для чисельного моделювання закачування газу у тріщинуваті колектори. Правильність методу підтверджується спрощеною моделлю мережі дискретного руйнування. Результати чисельного моделювання узгоджуються з результатами теоретичних розрахунків. Отримана імітаційна модель дискретної мережі тріщин. Встановлено рівняння збереження маси нафти, води, газу та закачаного газу у тріщинах і матриці. Створено рівняння багатофазного потоку рідини у різних середовищах.

Наукова новизна. Розроблено новий науково-методичний підхід до розрахунку та чисельного моделювання впорскування газу у тріщинуваті колектори, що враховує дискретну модель мережі тріщин.

Практична значимість. Методика чисельного моделювання поведінки тріщинуватого колектору може точно описати потоки нафти, води і газу у тріщині, що сприяє більш детальному вивченню механізму розвитку впорскування газу та його оптимізації.

Ключові слова: тріщинуватий колектор, чисельне моделювання, дискретна модель мережі тріщин, впорскування газу

\section{ИЗУЧЕНИЕ МЕТОДИКИ ЧИСЛЕННОГО МОДЕЛИРОВАНИЯ ВПРЫСКИВАНИЯ ГАЗА В ТРЕЩИНОВАТЫЕ КОЛЛЕКТОРЫ}

\section{3. Юнь, С. Цзяньфан, Л. Чжуньчунь}

Цель. Разработка новой методики численного моделирования впрыскивания газа в трещиноватые коллекторы на основе модели дискретной сети трещин.

Методика. Для достижения поставленной цели выполнен критический анализ известных методов моделирования, доказавший отсутствие на сегодняшний день эффективных методов. Для исследования проблемных вопросов в статье применен метод расчета фазового равновесия на основе свободной энергии Гиббса как основа для численного моделирования закачки газа. Использовали итерационный метод Ньютона для определения состава каждой фазы в минимуме свободной энергии Гиббса.

Результаты. На основе модели дискретной сети трещин сформированы математическая модель, численная модель и метод решения для численного моделирования закачки газа в трещиноватые коллекторы. Правильность метода подтверждается упрощенной моделью сети дискретного разрушения. Результаты численного моделирования согласуются с результатами теоретических расчетов. Получена имитационная модель дискретной сети трещин. Установлены уравнения сохранения массы нефти, воды, газа и закачанного газа в трещинах и матрице. Создано уравнение многофазного потока жидкости в различных средах.

Научная новизна. Разработан новый научно-методический подход к расчету и численному моделированию впрыскивания газа в трещиноватые коллекторы, учитывающий дискретную модель сети трещин.

Практическая значимость. Методика численного моделирования поведения трещиноватого коллектора может точно описать потоки нефти, воды и газа в трещине, что способствует более детальному изучению механизма развития впрыскивания газа и его оптимизации.

Ключевые слова: трещиноватый коллектор, численное моделирование, дискретная модель сети трещин, впрыскивание газа

\section{ARTICLE INFO}

Received: 7 January 2019

Accepted: 15 April 2019

Available online: 6 May 2019

\section{ABOUT AUTHORS}

Zhang Yun, Doctor of Philosophy in Oil and Gas Field Development, Senior Engineer of the Sinopec Petroleum Exploration and Production Research Institute, No. 31 Xueyuan Road, Haidian District, 100083, Beijing, China. E-mail: zhangyun.syky@sinopec.com

Sun Jianfang, Doctor of Philosophy in Oil and Gas Field Development, Professor of the Sinopec Petroleum Exploration and Production Research Institute, No. 31 Xueyuan Road, Haidian District, 100083, Beijing, China. E-mail: sunjf.syky@sinopec.com

Liu Zhongchun, Doctor of Philosophy in Oil and Gas Field Development, Professor of the Sinopec Petroleum Exploration and Production Research Institute, No. 31 Xueyuan Road, Haidian District, 100083, Beijing, China. E-mail: liuzc.syky@sinopec.com 